\title{
Tekmeria
}

Vol 9 (2008)

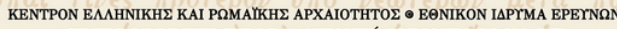
CENTRE DE RECHERCHE DE LANTIQUITÉ GRECQUE ET ROMAINE
FONDATION NATIONALE DE LA RECHERCHE SCIENTIFIQUE

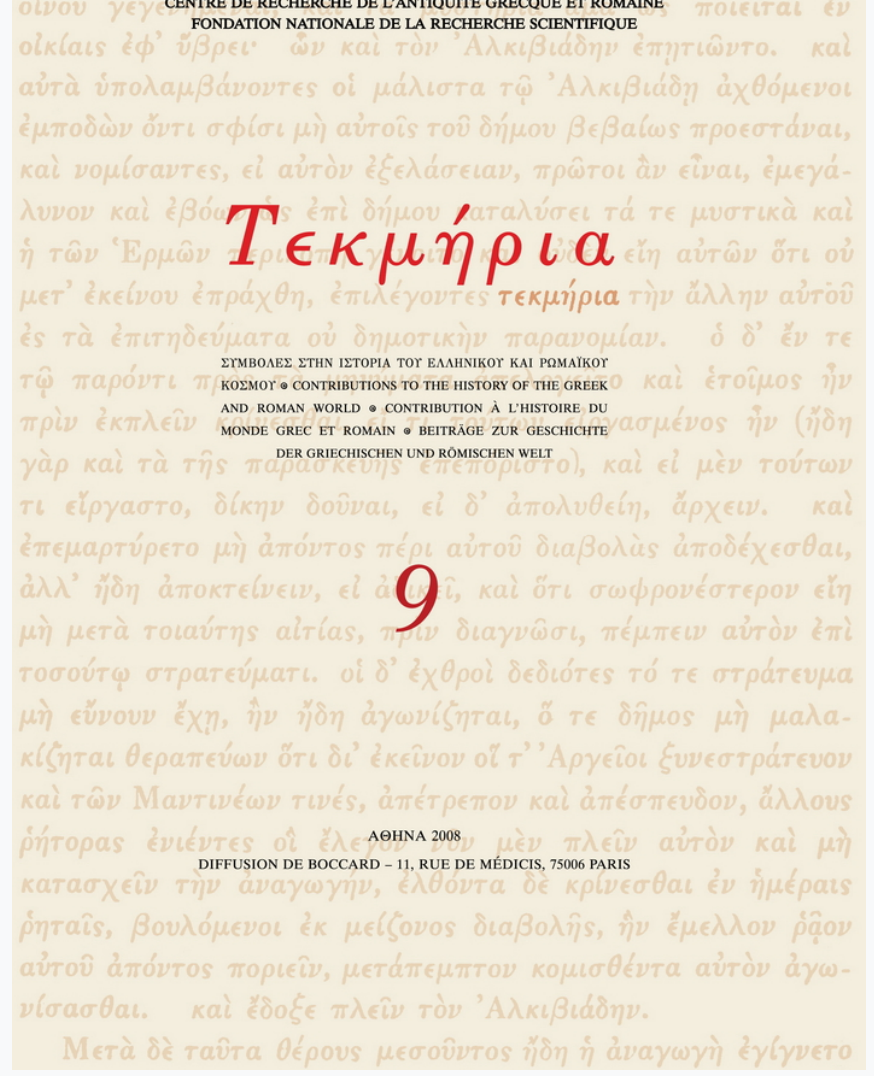

\section{New Inscriptions from late antique Aphrodisias}

A. CHANIOTIS

doi: $10.12681 /$ tekmeria.221

\section{To cite this article:}

CHANIOTIS, A. (2008). New Inscriptions from late antique Aphrodisias. Tekmeria, 9, 219-232.

https://doi.org/10.12681/tekmeria.221 


\section{New Inscriptions from late antique Aphrodisias}

In the years 1995-2007 a series of inscriptions dating from Late Antiquity (late 3rd7th cent.), mostly graffiti, were either found during the excavation or were seen by the author and other members of the excavation team in various buildings of the city. The most important of these inscriptions are presented in this article. ${ }^{1}$ I have not included graffiti, small fragments, individual letters, and inscriptions on pottery. The dates suggested for these texts are in most cases approximate. The dating criteria are the letter forms, ${ }^{2}$ the onomastics, and the use of certain expressions and religious symbols (especially of crosses). All dates are A.D. unless otherwise stated. I should like to express my warm thanks to the Directors of the Aphrodisias Excavation R.R.R. Smith (Oxford) and C. Ratté (New York, now Ann Arbor) for entrusting me with the study of this material and for supporting my research at Aphrodisias in the years 1995-1997 and 1999-2007; Joyce Reynolds (Cambridge) and Charlotte Roueché (London) for the permission to consult and refer to unpublished material; ${ }^{3}$ the Alexander S. Onassis Foundation for financing my research in 1997; the Dorot Foundation for a grant which enabled me to study the

1. The following abbreviations are used:

ALA: Charlotte Roueché, Aphrodisias in Late Antiquity, (London 1989).

e-ALA: Charlotte Roueché, Aphrodisias in Late Antiquity, electronic second edition, London 2004 (http://insaph.kcl.ac.uk/ala2004).

For the late antique inscriptions of Aphrodisias see $A L A$ and $e-A L A$. For the other inscriptions found in Aphrodisias during my research in the years 1995-2001 (including a fragment of Diocletian's price edict) see Angelos Chaniotis, «New Inscriptions from Aphrodisias (1995-2001)», AJA 108 (2004) 377-416.

2. For the letter forms in the late inscriptions of Aphrodisias see $A L A$, pp. 331-334.

3. See now the electronic publication of the largest part of this material in IAph 2007 (http://insaph.kcl.ac.uk/iaph2007/index.html). 
ANGELOS CHANIOTIS

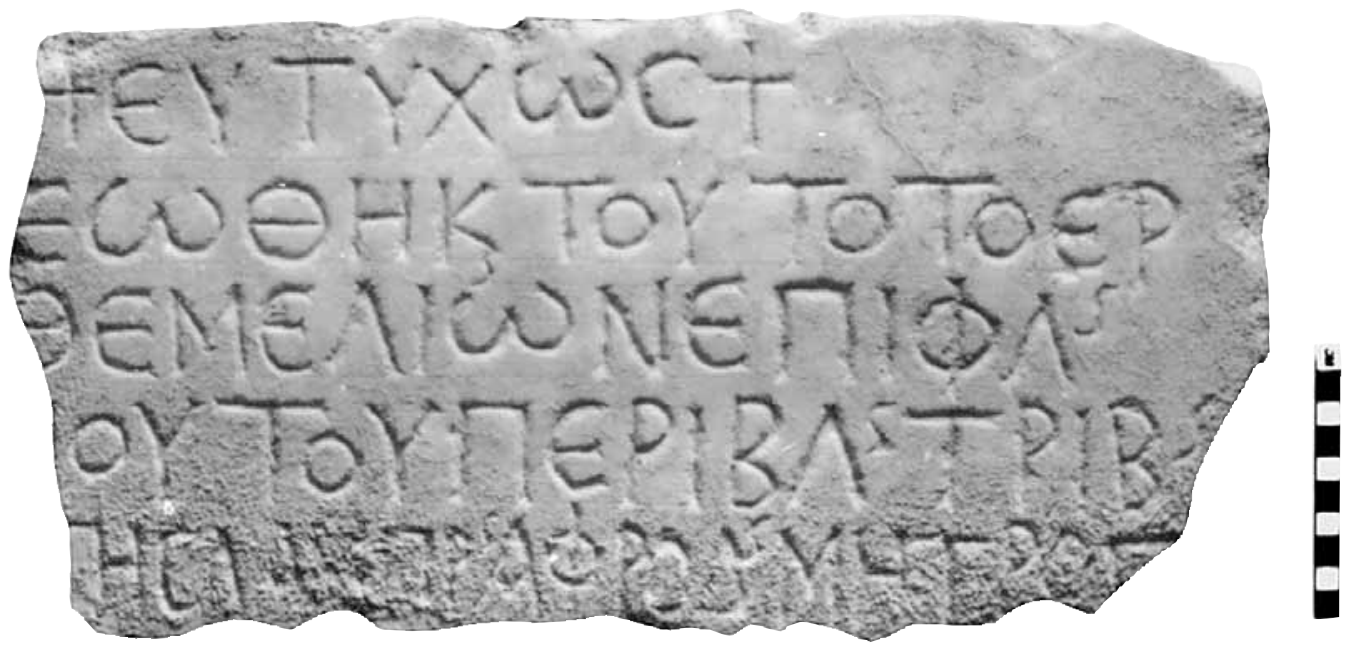

Fig. 1. Inscription no 1. 
epigraphic material in the years 1997-1998; and the Gisela and Reinhold Häcker Stiftung which supported my research in the year 2001.

\section{Inscription recording repairs to a building}

Inv. no. 02.024 (I 02.003). Marble plaque broken on the left side; found reused on the pavement at the southeast corner of the North Agora in 2002. (Fig. 1). Height $27.2 \mathrm{~cm}$, width $45 \mathrm{~cm}$, depth c. $4 \mathrm{~cm}$., letter height $2-4 \mathrm{~cm}$.

c. fifth century AD.

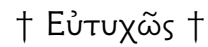

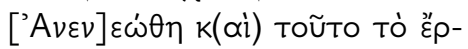

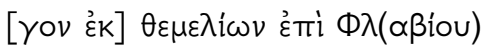

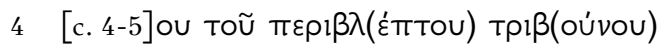

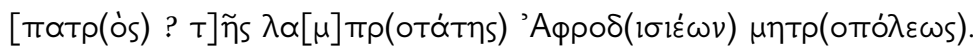

The text is written within double guidelines; cf. $A L A$ 157; SEG XXXVI 970 A. The abbreviation sign ${ }^{S}$ is used after the letters $\mathrm{K}$ (1. 2), $\Lambda$ (1. 3), $\Lambda$ and B (1. 4), and $\mathrm{P}, \Delta$ and $\mathrm{P}$ (1. 5).

With good fortune. This work too was renewed from the foundations up under Fl(avius) [---]us, spectabilis, tribunus, [father?] of the most splendid metropolis of the Aphrodisieis.

This text belongs to a large group of inscriptions recording building activities in late antique Aphrodisias, from the first half of the fourth to the sixth century. ${ }^{4}$ The restored building cannot be identified. The formulations used in this text have close parallels in contemporary inscriptions. ${ }^{5}$

The person responsible for the work had a high rank in the imperial administration, as the title $\pi \varepsilon \rho i \beta \lambda \varepsilon \pi \tau$ implies. In Aphrodisias this title is attested for

4. ALA 17-20, 22, 30, 34/35?, 38-40, 42-44, 51, 52, 56-58, 60, 62, 66, 67?, 72, 83, 87; SEG XL 949; XLVI 1398; cf. the comments of Charlotte Roueché in $A L A$, esp. pp. 35, 43f., 69-71, 79f. For building activities in Aphrodisias in late Antiquity see Christopher Ratté, «New Research on the Urban Development of Aphrodisias in Late Antiquity», in D. Parrish (ed.), Urbanism in Western Asia Minor. New Studies on Aphrodisias, Ephesos, Hierapolis, Pergamon, Perge and Xanthos, («JRA Suppl.» 45; Portsmouth 2001) 117-47, esp. 125-38.

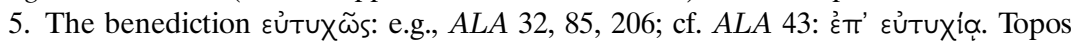

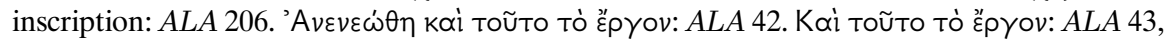
83, 90; SEG XL 949; cf. Louis Robert, Documents de l'Asie Mineure méridionale, (Paris 1966)

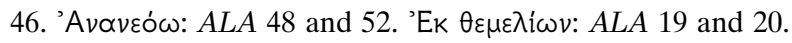




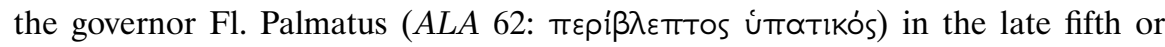
early sixth century. ${ }^{6}$ The same title is used for other tribuni: Taurus in Kos (Iscr. Cos EV 63, fourth/fifth century), Romulus in Diokletianoupolis (EAM $203+S E G$ XXXVII 475, fifth/sixth century), Faustinus in Prusa ad Olympum (I.Prusa 1095), Fl. Martyrius in Arabia (SEG XXXV 1582, c. 550), and an anonymous man in Tarsos (SEG XXXVII 1348). He probably was a trinunus et notarius likeTaurus, Romulus, and Faustinus. ${ }^{7}$

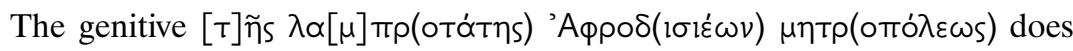
not refer to this office, since the tribuni et notarii did not have a local assignment. It is

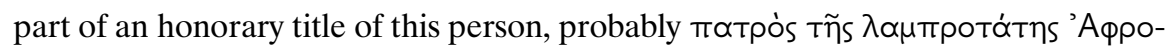
$\delta ı \varepsilon^{\varepsilon} \omega \nu \mu \eta т р о т о ́ \lambda \varepsilon \omega s$. This title is attested for Fl. Athenaios in the late fifth or early

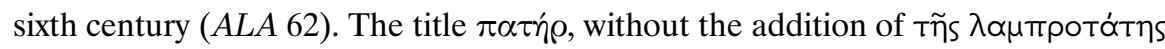

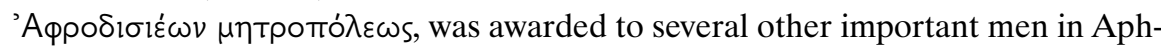
rodisias, the scholastici Fl. Ampelius (ALA 22 and 43), Fl. Photius (ALA 69 and 238), and Rhodopaiaos ( $A L A 85$ ), and the councillor Theopompos ( $A L A 89$ ). Another

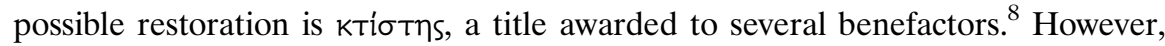
when it is followed by the name of the city it is used for governors. ${ }^{9}$ The title

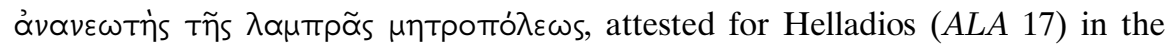
fourth century seems to long, but we cannot exclude an abbreviation. ${ }^{10}$ The title

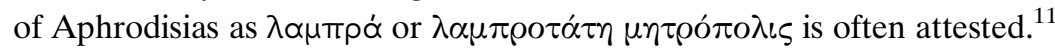

The name Flavius (post-Constantine), the use of the cross, and the letter forms suggest a date after c. 350. The use of the title $\pi \varepsilon \rho i \beta \lambda \varepsilon \pi \tau$. makes a date in the fifth century most likely.

\section{Fragment of a Christian dedication}

Inv. No. 01.012 (I 01.031). Fragment of a marble pedestal with moulding and feet

6. Other governors with this title, e.g, I.Ephesos $1032+$ SEG XXXVI 1032 (sixth century); SEG XXXVII 1321-1322 (comes, fifth/sixth century); SEG XLII 991 (c. 518-527); I.Side 171 .

7. Denis Feissel, «Inventaires en vue d'un recueil des inscriptions historiques de Byzance, IV: Inscriptions de Thessalie (à l'exception des Météores)», TEMByz 10 (1987) 362.

8. ALA 7, 14, 39, 40, 62, 83, 87.

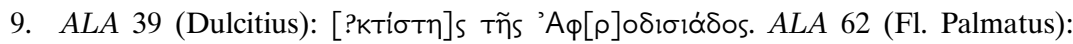

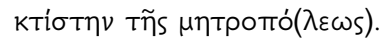

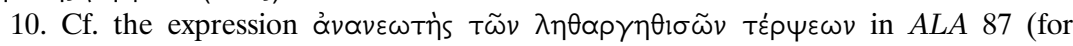
Rhodopaios).

11. ALA 17, 19, 42, 43, 62, 65 . 
NEW INSCRIPTIONS FROM LATE ANTIQUE APHRODISIAS

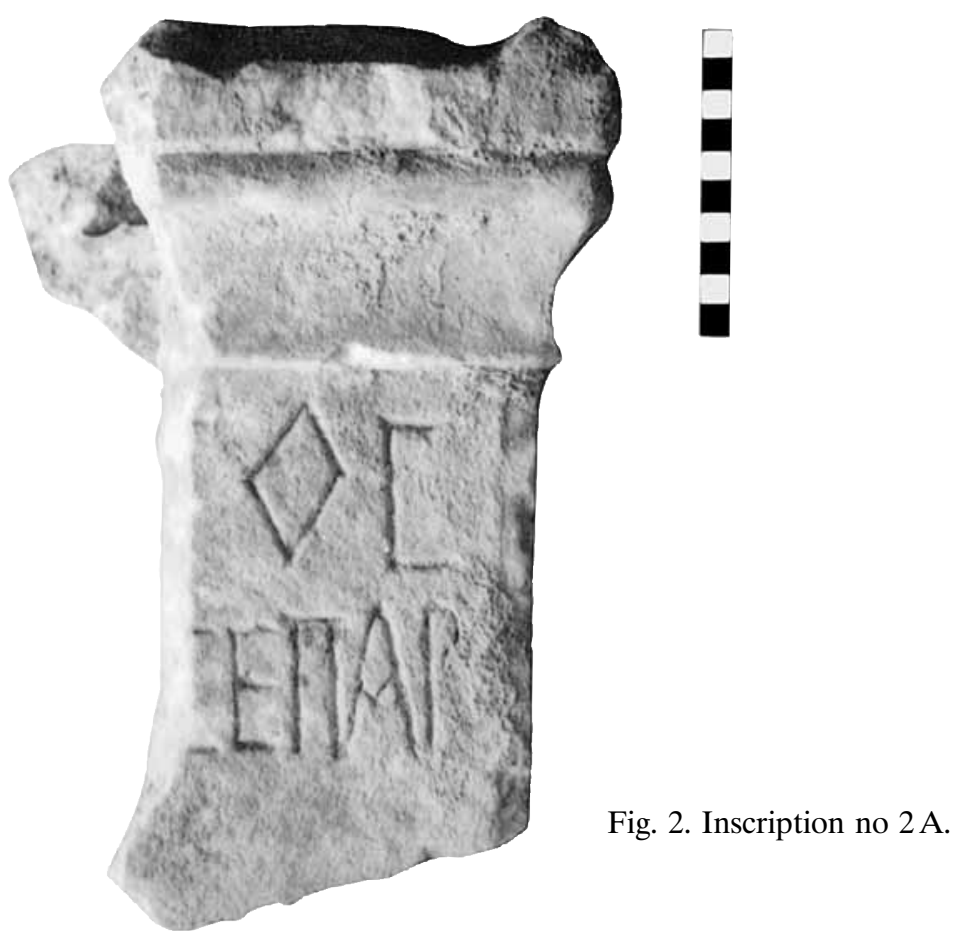

Fig. 3. Inscription no $2 \mathrm{~B}$.

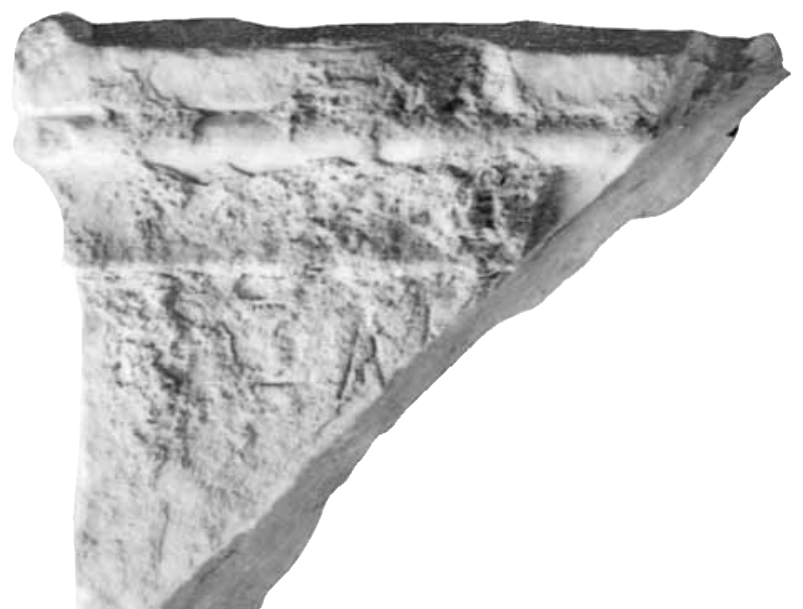


on the bottom, broken on the top and on two sides. When it was reused, it was turned around and inscribed on two adjacent faces. (Figs. 2-3). It is not certain whether the deep hole on the stone was made in the period of its second use or even later. Stray find in a field in the south necropolis. Height $31 \mathrm{~cm}$, width $38 \mathrm{~cm}$, depth $23 \mathrm{~cm}$ (preserved), letter height $5-5.5 \mathrm{~cm}$ (A), $4.2 \mathrm{~cm}$ (B). Found in a field in the south necropolis.

Fourth century AD or later.
A $\quad[--\cdots---1.05$
[--- - - ] ș દ̇ $\pi \alpha \rho-$
B $\quad[\varepsilon \cup ̉] \xi \alpha \dot{\alpha} \mu[\varepsilon v o s ?]$

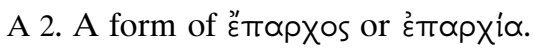

\section{Christian prayer of Prokopios}

I 00.002. Three joining fragments of a marble plaque, decorated with an engraved circle which encloses a cross and two birds. A hole in the centre of the plaque was made when it was reused. The upper left corner and the entire lower left quarter are missing. (Figs. 4-5). Found by Laura Hebert in the Temple-Church. Height $75 \mathrm{~cm}$, length $90 \mathrm{~cm}$, depth $8 \mathrm{~cm}$. An inscription is engraved above the circle. Letter height $1.7-2 \mathrm{~cm}$.

c. fifth century $\mathrm{AD}$ or later.

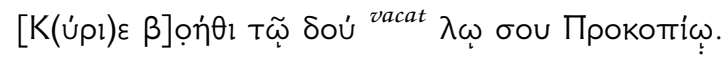

God, help Prokopios, your servant.

Similar prayers have been found in the Temple-Church. ${ }^{12}$ The name Prokopios is already attested in Aphrodisias in Late Antiquity, for a theosebes (fourth century) ${ }^{13}$ and for a Christian (sixth/seventh century). ${ }^{14}$ The popularity of the name increased after the 3 rd cent. ${ }^{15}$

12. ALA 117 and 118.

13. SEG XXXVI 970, 4th century; for the date of this inscription see Angelos Chaniotis, «The Jews of Aphrodisias: New Evidence and Old Problems», SCI 21 (2002) 209-242.

14. ALA 91 (IAph2007 15.363).

15. Chaniotis, ibid., 235. 
NEW INSCRIPTIONS FROM LATE ANTIQUE APHRODISIAS

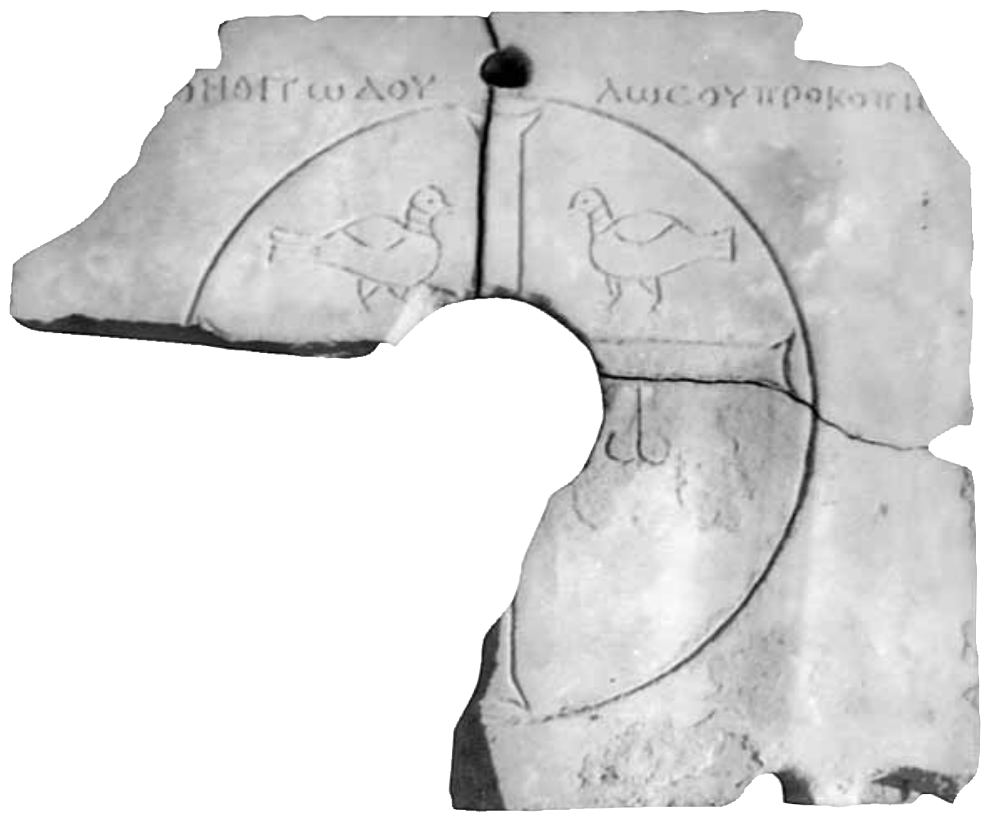

Fig. 4. Inscription no. 3.

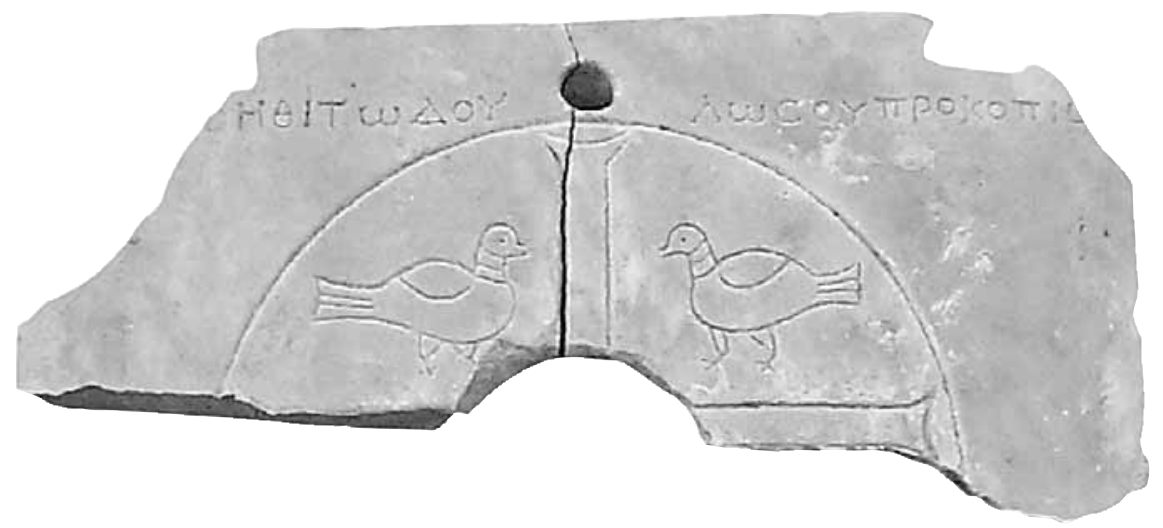

Fig. 5. Inscription no. 3 (detail). 
ANGELOS CHANIOTIS

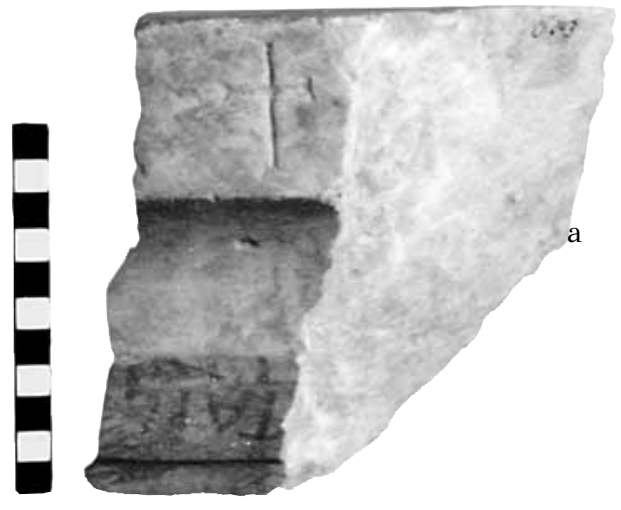

Figs. 6-8. Inscription no. 4, frs. a, b, c.
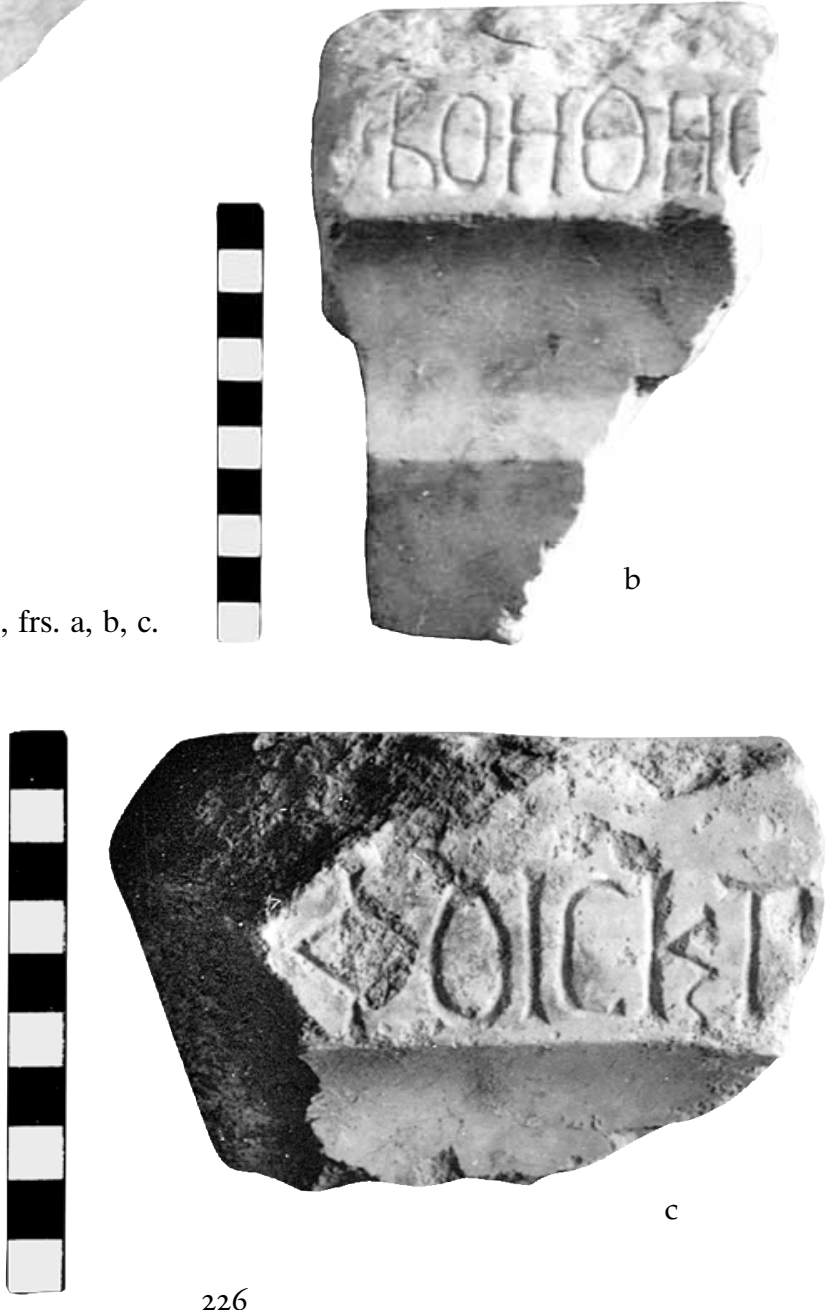


\section{Christian prayer}

I 99.004. Three non-joining fragments of a marble screen. a) Broken on the right and the left side and at the bottom. Height $15 \mathrm{~cm}$, length $19 \mathrm{~cm}$, depth $19 \mathrm{~cm}$. Inscribed with a cross $(3.5 \mathrm{~cm}$.). b) Broken on the right and the left side and at the bottom. On the flat top a small cross $(2 \mathrm{~cm})$. Height $15 \mathrm{~cm}$, length $11 \mathrm{~cm}$, depth 19 $\mathrm{cm}$; letter height $2.5-2.7 \mathrm{~cm}$. c) Broken on the right and left sides, on the back, and on the bottom. Height $8 \mathrm{~cm}$, length $10 \mathrm{~cm}$, depth $11 \mathrm{~cm}$, letter height $2.5-3.3 \mathrm{~cm}$. (Figs. 6-8). Found during the removal of architectural fragments placed in rear chamber 6 of the Bouleuterion, originally from the area of the Temple-Church.

c. fifth century $\mathrm{AD}$ (or later).

$$
\begin{aligned}
& \begin{array}{lll}
a & b & c
\end{array}
\end{aligned}
$$

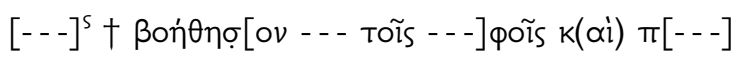

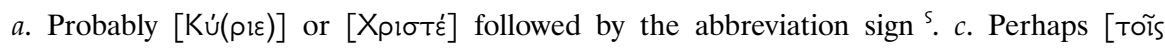
$\left.{ }_{\alpha} \delta \varepsilon \lambda\right] \phi o$ ĩs. After the $\mathrm{K}$, the abbreviation sign ${ }^{\mathrm{s}}$.

[Lord?] help [the brothers?] and [---].

Christian inscriptions of the $\beta \circ \eta \dot{\theta} \varepsilon / \beta \circ \eta \eta \eta\rceil \sigma \nu$ type are very common in Aphrodisias. ${ }^{16}$

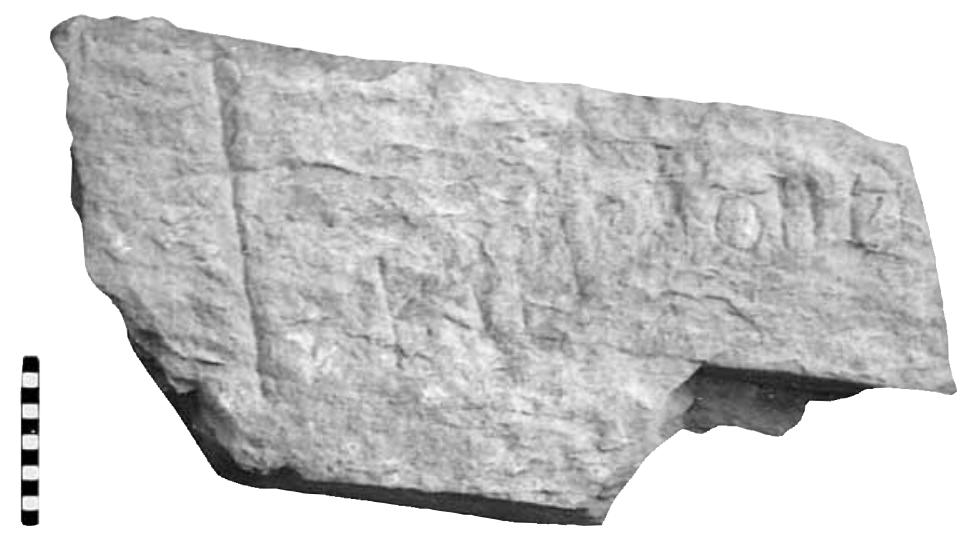

Fig. 9. Inscription no 5.

16. ALA 92-94, 97, 113 ii, 117 i, 118 iii, 125, 129 iii, 132 ii, 134 i-ii, 135, 136, 137 i, iv, 141, 142, 145, 174. 


\section{Christian prayer}

Inv. No. 01.013 (I 01.030). Fragment broken on all sides. (Fig. 9). Height $29 \mathrm{~cm}$, width $57 \mathrm{~cm}$, depth $13.5 \mathrm{~cm}$, letter height $3.5-6.5 \mathrm{~cm}$. Found in the stone quarries.

c. fifth century $\mathrm{AD}$ or later.

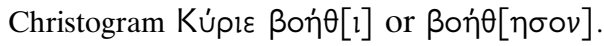

This common Christian prayer formula is often attested in Aphrodisias. ${ }^{17}$

\section{Fragment}

I 99.006. Fragment of a marble block, broken on all sides, inscribed with letters engraved carelessly. (Fig. 10). Height $16 \mathrm{~cm}$, width $17 \mathrm{~cm}$, depth $13 \mathrm{~cm}$; letter height $0.7-1.5 \mathrm{~cm}$. Found during the removal of architectural fragments placed in rear chamber 6 of the Bouleuterion, originally from the area of the Temple-Church.

Third century AD (or later).

$$
\begin{aligned}
& \text { TN } \\
& {[---] 10 \text { oikovo- }} \\
& {[---] \quad \text { I }}
\end{aligned}
$$

1 An oblique stroke above the $\mathrm{N}$; the number 350? 2 A form of oikovónos or of the verb

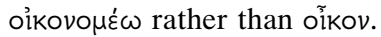

For an oikonomos in Aphrodisias see PPA $45.11 \mathrm{G}$. The verb oikovo $\mu \varepsilon \dot{\omega} \omega$ is

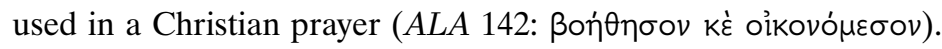

\section{Invocation}

I 99.005. Marble cornice with moulding on three sides, broken on the back. (Fig. 11). Height $27 \mathrm{~cm}$, width $42 \mathrm{~cm}$, depth $29 \mathrm{~cm}$ (bottom) $40 \mathrm{~cm}$ (top), letter height 4.5-5 cm. Found during the removal of architectural fragments placed in rear chamber 6 of the Bouleuterion, originally from the area of the Temple-Church.

c. fourth century $\mathrm{AD}$.

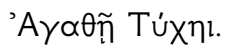

This invocation is often used in late antique contexts, usually in honorary inscriptions. $^{18}$

17. ALA 94, 136, $137 \mathrm{i}$ and 142 .

18. Cf. $A L A$ 26, 27, 62, 82, 85, 87. 


\section{Christian invocation}

I 99.029. Marble capital of a column (fig. 12), broken on the left side; inscribed in a panel $(42 \times 14 \mathrm{~cm})$. Height $29 \mathrm{~cm}$, width $78 \mathrm{~cm}$, depth $45 \mathrm{~cm}$, letter height $5 \mathrm{~cm}$. Found by Michelle Berenfeld in the 'Bishop's Palace'.

c. fifth century AD.

$$
\left[{ }^{\prime} A\right] \gamma \propto \theta \tilde{n}+T u ́ x \eta n .
$$

Cf. the text no. 7.

\section{Epitaph of Ioulianos}

I 02.014. Upper part of a marble plaque found in the Temple-Church in 2002; a frame surrounds an undecorated panel. The inscription is written on the frame. For a similar plaque cf. $A L A$ 175. (Fig. 13). Height $41 \mathrm{~cm}$, width $66 \mathrm{~cm}$, depth $15.5 \mathrm{~cm}$, letter height 3-4 cm. Found in the Temple-Church.

c. fourth century AD.

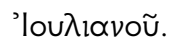

The name Ioulianos is quite common in Aphrodisias. ${ }^{19}$

\section{Epitaph of Theodoretos}

I 02.020. Marble plaque (cf. no. 9) found by Michele Berenfeld built in the east wall of room 29 of the so-called Bishop's Palace, only partly visible. (Fig. 14). Height c. 1 $\mathrm{m}$, width $83 \mathrm{~cm}$, depth $14 \mathrm{~cm}$, letter height at least $7.5 \mathrm{~cm}$.

Fourth century $\mathrm{AD}$ or later.

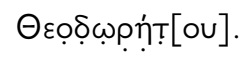

Or $\Theta \varepsilon \circ \delta \omega \rho \eta \dot{t}[\alpha \varsigma]$.

19. Joyce Reynolds, Aphrodisias and Rome, (London 1982) 113-115 no. 14; J.M.R. Cormack, «Inscriptions from Aphrodisias (found in 1893)», BSA 59 (1964) 19 no. 10; G. Doublet - G. Deschamps, «Inscriptions de Carie - II. Ghiéra (Aphrodisias)», BCH 14 (1890) 607 no. 3; MAMA VIII 510, 551, 564; Charlotte Roueché, Performers and Partisans at Aphrodisias, (London 1993) 18 no. 1.5.iii, 166 no. 51 line 19, 176-178 no. 55. The name also appears in several unpublished texts. 
ANGELOS CHANIOTIS

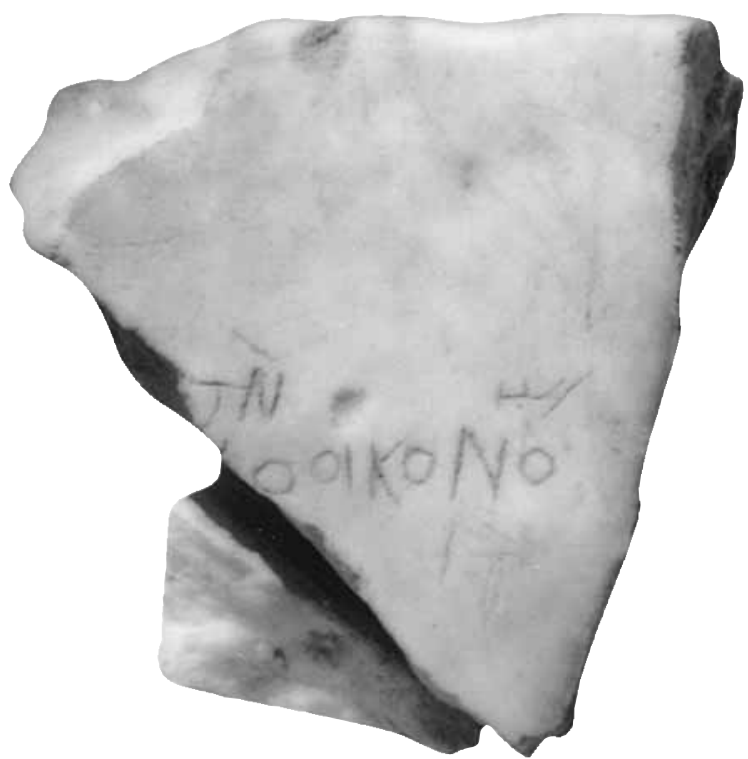

Fig. 10. Inscription no 6.

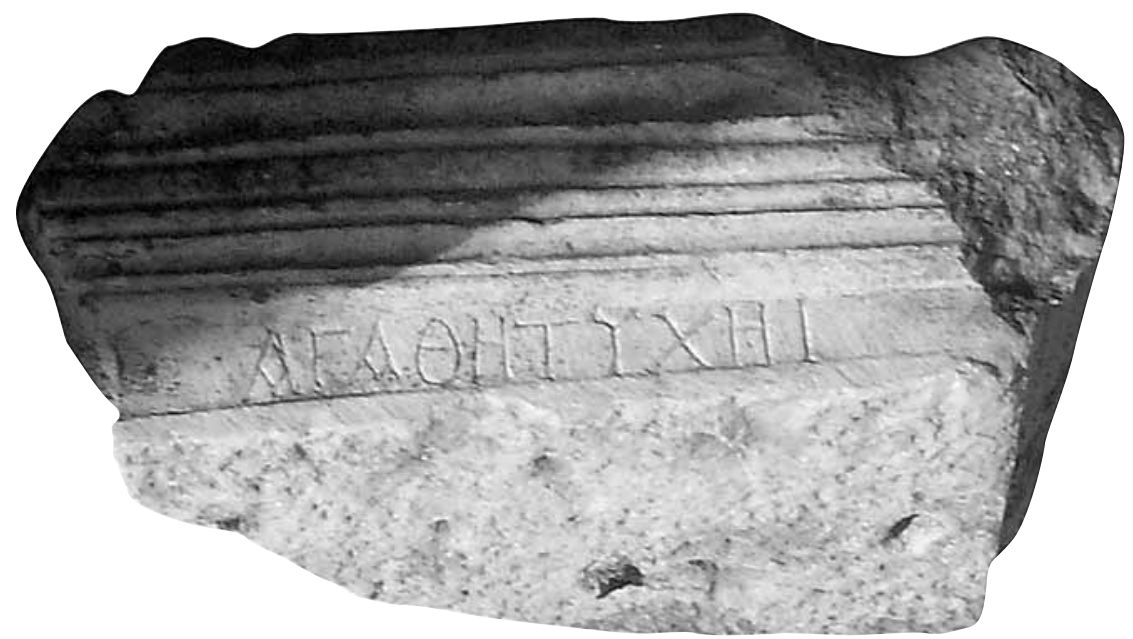

Fig. 11. Inscription no 7. 
The personal names Theodoretos ( $A L A$ 92-93) and Theodoreta are attested among the early Christian population of Aphrodisias ( $A L A$ 164).

\section{Fragment with a monogram}

Inv. No. 01.022 (I 01.006). Fragment of a marble plaque broken on all sides, found in the room north of the apse of the Temple-Church, in a stone storage pile. Height $16 \mathrm{~cm}$, width $8.5 \mathrm{~cm}$, depth $4.3 \mathrm{~cm}$, letter height $7 \mathrm{~cm}$.

Fourth century $\mathrm{AD}$ or later.

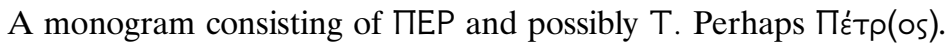

\section{Summary}

This article presents 11 new inscriptions found during the recent excavations at Aphrodisias in Asia Minor (1995-2007). A building inscription (1, c. 5th cent. AD) commemorates the restauration of an unknown building by the $\pi \varepsilon \rho i \beta \lambda \varepsilon \pi \tau$ то трıßоũvos Flavius [---]. This is the first attestation of this office of the Imperial admnistration in Aphrodisias. The anonymous

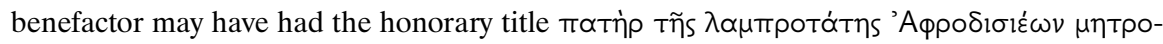
тó $\lambda \varepsilon \omega s$. The other inscriptions include a fragmentary Christian dedication (2, c. 4th cent. $\mathrm{AD})$, three Christian prayers $(3-5$, c. 5 th cent. $\mathrm{AD})$, one of which preserves the name Проко́тাоs (3), a fragment mentioning an oíkovómos or oíkovómol (6, 3rd cent. AD), parts

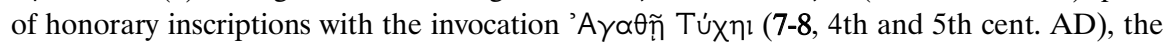

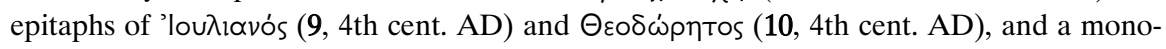
gram (Пв́троs?) on a plaque (11, 4th cent $\mathrm{AD})$. 


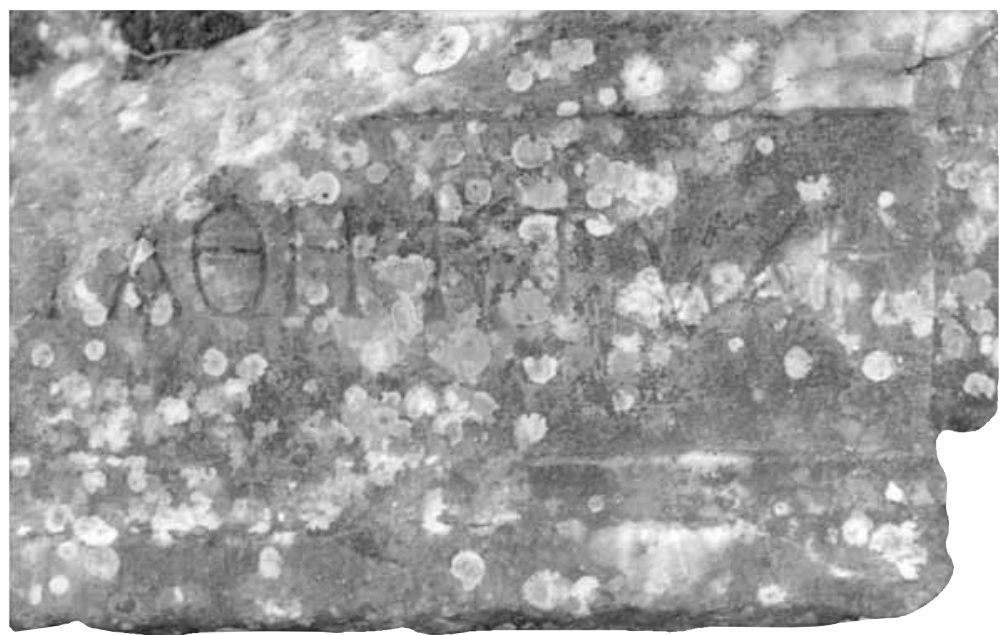

Fig. 12. Inscription no 8.

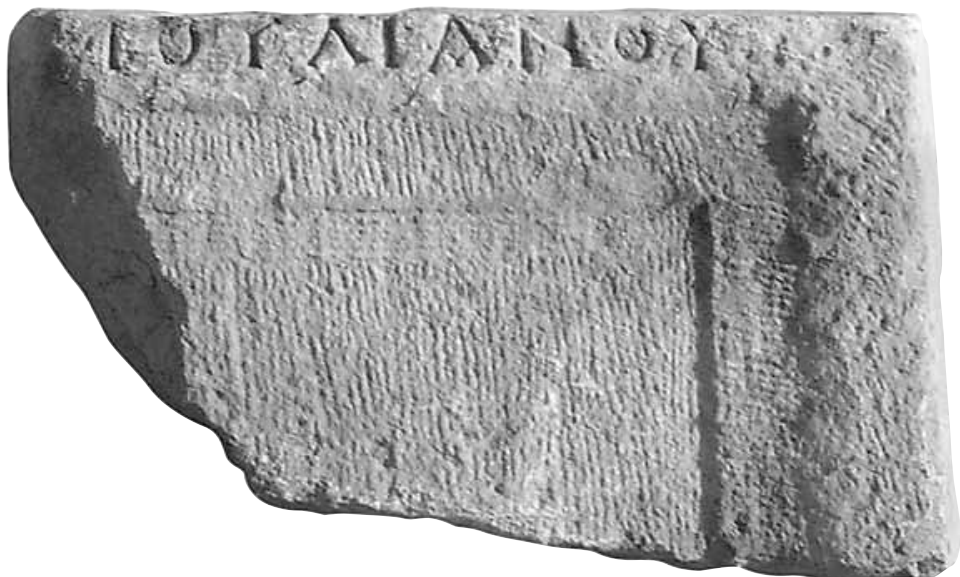

Fig. 13. Inscription no 9.

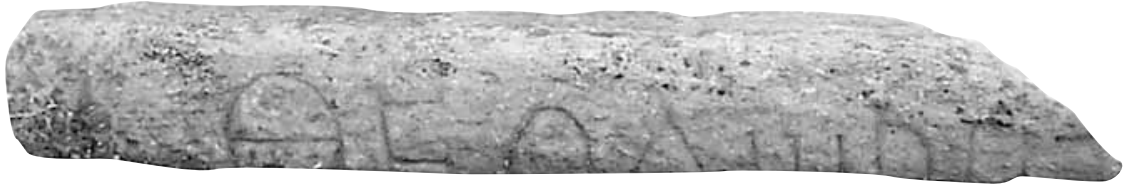

Fig. 14. Inscription no 10. 